\section{Long-term study of somatic dysfunction required}

Epidemiology should be regarded as a basic science for all of clinical medicine, including somatic dysfunction and its relationship to health and disease as articulated by the osteopathic medical profession. Yet, for physicians to develop an epidemiologic basis for clinical medicine, “... require[s] the particularization, to the individual patient, of our prior experiences (both as individual clinicians and collectively) with groups of similar patients."1

With that in mind, Myron Beal, DO, examines the incidence of spinal palpatory findings with his review of nine separate studies, beginning on page 1027 of this issue. Dr Beal identifies several factors influencing the incidence of somatic dysfunction, such as posture, short leg, pronation syndrome, handedness, transitional areas of the spine, and visceral reflexes.

These observations suggest an avenue for establishing epidemiologic protocols in this area. As such, standardized medical records of osteopathic diagnostic tests and treatment procedures would need to be developed as part of the overall research design. This, in turn, could be used to acquire a base of information with which disease states may be compared.

Generally, longitudinal studies of neuromusculoskeletal reflectance in health and disease have not been performed. Had studies been done, those factors that influence the diagnosis of somatic dysfunction would already be realized. Until such studies are undertaken, the meaning of somatic dysfunction remains incomplete. This presents the osteopathic medical profession with a challenge to totally define the meaning of somatic dysfunction through continued, comprehensive research.

ANTHONY G. CHILA, DO,

Professor and Chairman

Department of Family Medicine

Chief of Clinical Research

Ohio University College of

Osteopathic Medicine

Athens, Ohio

\section{September designated as National Cholesterol Education Month}

The National Cholesterol Education Program (NCEP), under the auspices of the National Heart, Lung, and Blood Institute, has designated September as the first National Cholesterol Education Month. This special focus exemplifies but one phase in the ongoing effort to reduce Americans' cholesterol levels, and hence the incidence of coronary heart diease, morbidity, and mortality.

As a participating member of the NCEP, the American Osteopathic Association and its members have an opportunity to spread cholesterol awareness to the public. That means getting the word out regarding desirable blood cholesterol levels. (NCEP guidelines for adults age 20 and older designate $200 \mathrm{mg} / \mathrm{dL}$ as desirable, while 200 to 239 $\mathrm{mg} / \mathrm{dL}$ is considered borderline-high, and $240 \mathrm{mg} /$ $\mathrm{dL}$ and above is high.) But disseminating cholesterol awareness requires more than simply informing patients of their cholesterol "number."

Patients should know what role blood cholesterol plays in overall health and how they can reduce high cholesterol levels through behavior modification-diet, exercise, smoking cessation. To that end, the NCEP has developed educational materials (handouts, posters, radio scripts, sample news releases) that physicians may use to promote cholesterol awareness locally. Information regarding this public relations campaign may be obtained from the NCEP Information Center, 4733 Bethesda Ave, Suite 530, Bethesda, MD 20814.

As primary care providers, we osteopathic physicians have an obligation to make preventive healthcare more than just an annual campaign in our patients' lives.

STEPHEN E. WEIS, DO

AOA NCEP Representative

Department of Medicine

Assistant professor

Texas College of Osteopathic

Medicine

Fort Worth, Tex 


\section{Hay fever sufferers \\ have good reason to be confused}

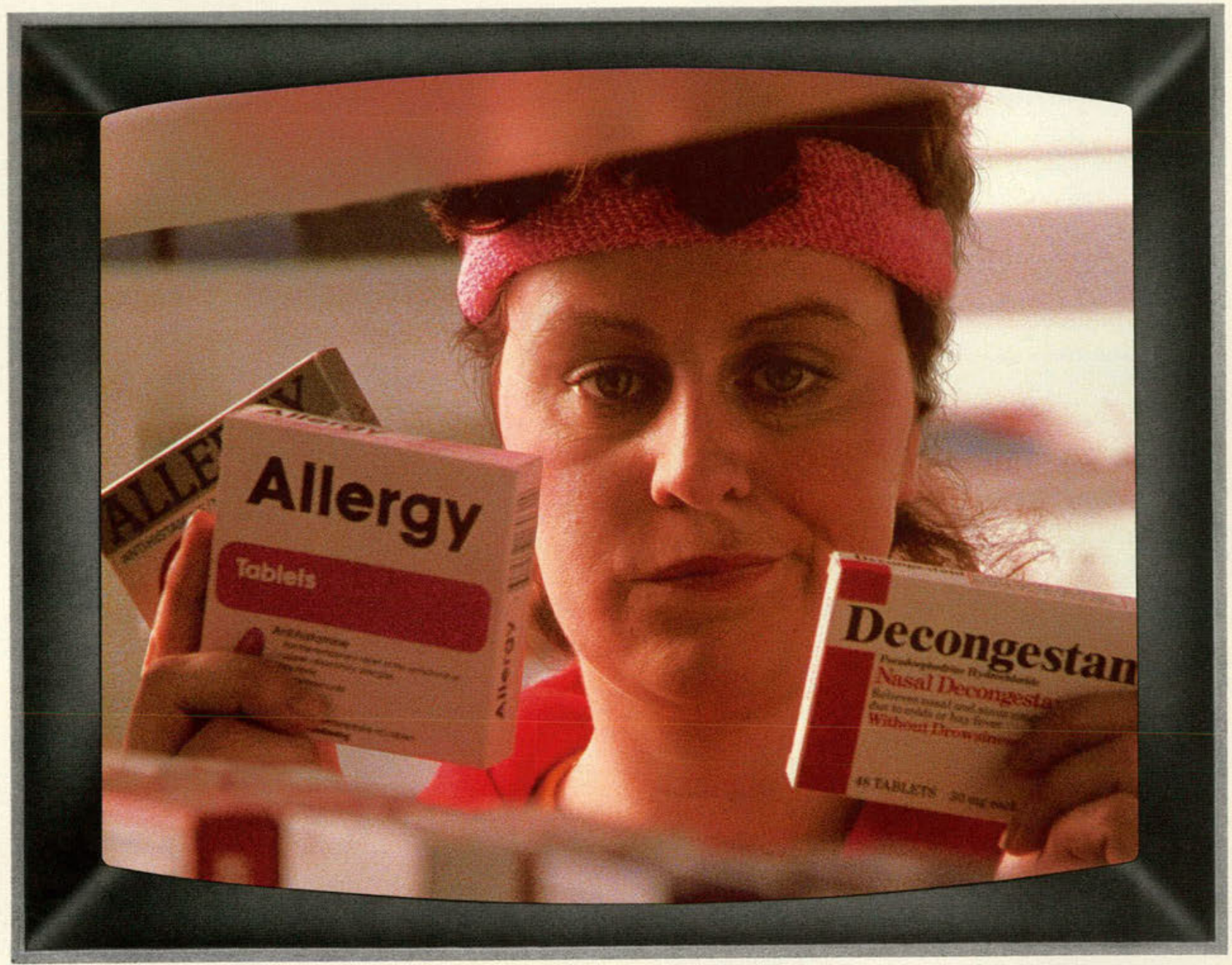

"All those products... all those ingredients.... all those claims - It can be very confusing."

Merrell Dow Pharmaceuticals Inc. nationwide "Allergy Awareness" campaign is advising them to see you.

\section{Only you can choose the best treatment}




\section{Only SELDANE provides fast, unsurpassed relief ${ }^{1.5}$ that lets patients stay alert ${ }^{1,7}$ so they can perform at their best}

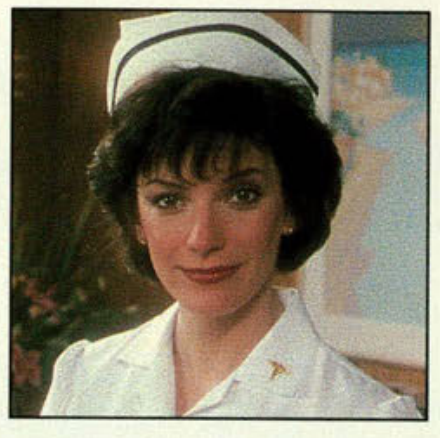

\section{Seldane ${ }^{\circledR}$ (terfenadine) $60 \mathrm{mg}$ Tablets}

CAUTION: Federal law prohibits dispensing without prescription.

DESCRIPTION

Seldane (terfenadine) is available as tablets for oral administration. Each tablet contains $60 \mathrm{mg}$ terfenadine. Tablets also contain, as inactive ingredients: corn starch, gelatin, lactose, magnesium stearate, and sodium bicarbonate.

Seldane is indicated for the relief of symptoms associated with seasonal allergic rhinitis such as Seldane is indicated for the relief of symptom
sneezing, rhinorrthea, pruritus, and lacrimation.

cONTRAINDICATIONS

CONTRAINDICATIONS
Seldane is contraindicated in patients with a known hypersensitivity to terfenadine or any of its ingredients.

PRECAUTIONS

Information for patients

Patients taking Seldane should receive the following information and instructions. Antihistamines are prescribed to reduce allergic symptoms. Patients should be questioned about pregnancy or lactation before starting Seldane therapy, since the drug should be used in pregnancy or lactation only if the potential benefit justifies the potential risk to fetus or baby. Patients should be instructed to take Seldane only as needed and not to exceed the prescribed dose. Patients should also be instructed to store this medication in a tightly closed container in a cool, dry place, away from heat or direct sunlight, and away from children.

Carcinogenesis, mutagenesis, impairment of fertility

Oral doses of tertenadine, corresponding to 63 times the recommended human daily dose, in mice for 18 months or in rats for 24 months, revealed no evidence of tumorigenicity. Microbial and micronucleus test assays with terfenadine have revealed no evidence of mutagenesis.

Reproduction and fertility studies in rats showed no effects on male or female fertility at oral doses of up to 21 times the human daily dose. At 63 times the human daily dose there was a small but significant reduction in implants and at 125 times the human daily dose reduced implants and increased post-implantation losses were observed, which were judged to be secondary to maternal toxicity. Pregnancy Category $C$

There was no evidence of animal teratogenicity. Reproduction studies have been performed in rats at doses 63 times and 125 times the human daily dose and have revealed decreased pup weight gain and survival when terfenadine was administered throughout pregnancy and lactation. There are no adequate and well-controlled studies in pregnant women. Seldane should be used during pregnancy only if the potential benefit justifies the potential risk to the fetus.

Nonteratogenic effects

Seldane is not recommended for nursing women. The drug has caused decreased pup weight gain and survival in rats given doses 63 times and 125 times the human daily dose throughout pregnancy and lactation. Effects on pups exposed to Seldane only during lactation are not known, and there are no adequate and well-controlled studies in women during lactation.

Pediatric use

Safety and effectiveness of Seldane in children below the age of 12 years have not been established. General

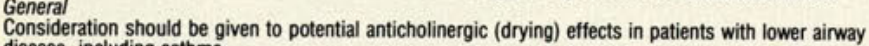
disease, including asthma.

\section{ADVERSE REACTIONS}

Experience from clinical studies, including both controlled and uncontrolled studies involving more than 2,400 patients who received Seldane, provides information on adverse experience incidence for periods of a tew days up to six months. The usual dose in these studies was $60 \mathrm{mg}$ twice daily, but in a small number of patients, the dose was as low as $20 \mathrm{mg}$ twice a day, or as high as $600 \mathrm{mg}$ daily.

In controlled clinical studies using the recommended dose of $60 \mathrm{mg}$ b.i.d., the incidence of reported adverse effects in patients receiving Seldane was similar to that reported in patients receiving placebo. (See Table below.)

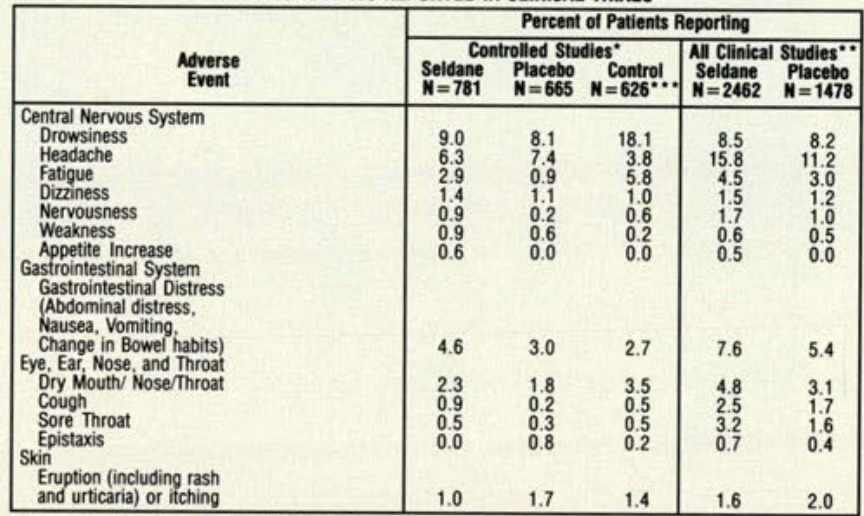

"Duration of treatment in "CONTROLLED STUDIES" was usually 7-14 DAYS
$\because$ Duration of treatment in "ALL CLINICAL STUDIES" was up to 6 months.

CONTROL DRUGS: Chlorpheniramine (291 patients), d-Chlorpheniramine (189 patients), Clemastine (146 patients)

In addition to the more frequent side effects reported in clinical trials (See Table), adverse effects have been reported at a lower incidence in clinical trials and/or spontaneously during marketing of Seldane that warrant listing as possibly associated with drug administration. These include: alopecia (hair loss or thinning), anaphylaxis, angioedema, arrhythmia (including ventricular tachyarrhythmia), bron. chospasm, confusion, depression, galactorrhea, hypotension, insomnia, menstrua disorders (including dysmenorrhea), musculoskeletal symptoms, nightmares, palpitation, paresthesia photosensitvity, prolonged QT interval, seizures, sweating, syncope, tachycardia, tremor, urinary frequency, and visual disturbances. In clinical trials, several instances of mild, or in one case, moderate transaminase elevations were seen in patients receiving Seldane. Mild elevations were also seen in placebo treated patients. Marketing experiences include isolated reports of jaundice, cholestatic hepatitiss, and hepatitis: in most cases available information is incomplete. In neither the clinical trials nor marketing experience is a causal relationship of liver abnormalities to Seldane use clear.

OVERDOSAGE

Information concerning possible overdosage and its treatment appears in Full Prescribing Information. DOSAGE AND ADMINISTRATION

The usual dosage for adults and children 12 years and older is $60 \mathrm{mg}$ (1 tablet) twice daily.

Product Information as of June, 1988

Y352D

MERRELL DOW U.S.A.

A Division of Merrell Dow Pharmaceuticals inc

Merrell Dow U.S.A.

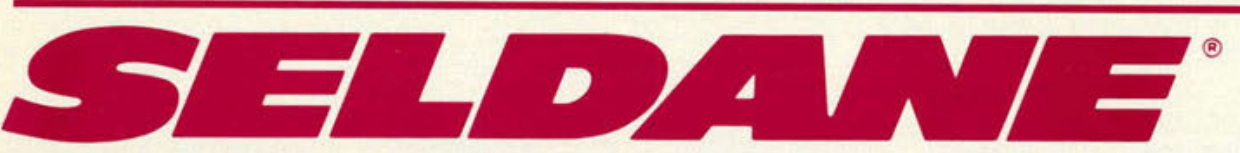

(terfenadine) $60 \mathrm{mg}$ tablets BID

for seasonal allergic rhinitis

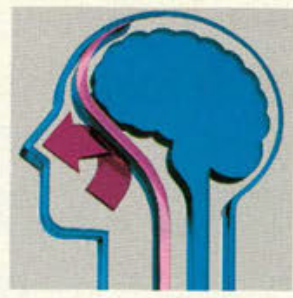

\section{The \# 1 prescribed allergy product in the U.S. and worldwide*}

\section{*Based upon worldwide prescription and distribution information (1986-1988) - data on file}

References: 1. Data on file, MERRELL DOW PHARMACEUTICALS INC., Cincinnati, Ohio 45215. 2. Kemp JP. Buckley CE, Gershwin ME, et al: Multicenter, double-blind placebo-controlled trial of terfenadine in seasonal allergic rhinitis and conjunctivitis. Ann Allergy 1985:54:502-509. 3. Backhouse CI, Brewster BS, Lockhart JDF, et al: Terfenadine In allergic rhinitis. A comparative trial of a new antihistamine versus chlorpheniramine and placebo. Practitioner 1982:226:347-348, 351. 4. Buckley CE, Buchman E, Falliers CJ, et al: Terfenadine treatment of fall hay fever. Ann Allergy 1988;60:123-128. 5. Melillo G. D'Amato G. Zanussi C, et al: A multicentre controlled trial of terfenadine dexchlorpheniramine, and placebo in allergic rhinitis. Arzneim-Forsch/Drug Res 1982:32:1202-1203. 6. Fink M, Irwin P. CNS effects of the antihistamines diphenhydramine and terfenadine (RMI 9918). Pharmakopsychiat 1979:12:35-44. 7. Roehrs TA, Tietz El, Zorick FJ, et al: Daytime sleepiness and antihistamines. Sleep 1984;7:137-141. 